\title{
Association Analysis among Fungi Colonizing Wheat Crop Residues During Decomposition for Sustainable and Environment-Friendly Management of Renewable Natural Resources
}

\author{
Raj Singh ${ }^{1(\mathbb{D})}$, Sushil Kumar Upadhyay ${ }^{1 *}{ }^{\mathbb{D}}$, Tarun Kumar Upadhyay ${ }^{2}{ }^{\mathbb{D}}$, Bikram Jit Singh ${ }^{3(\mathbb{D}}$, Anju \\ Rani ${ }^{4}$ (i), Chhaya Singh 5 (i)
}

1 Department of Biotechnology, Maharishi Markandeshwar (Deemed to be University), Mullana-Ambala (Haryana)133207, India

2 Faculty of Biotechnology, School of Applied sciences and Agriculture Research, Suresh Gyan Vihar University, Jaipur (Rajasthan), India

3 Department of Mechanical Engineering, Maharishi Markandeshwar (Deemed to be University), Mullana-Ambala (HR), India

4 Department of Botany, KV Subharti College of Science, Swami Vivekanand Subharti University, Meerut (UP), India

5 Government Degree College, Thalisain (Uttarakhand), India

* Correspondence: upadhyay.k.sushil@gmail.com;

Received: 7.01.2021; Revised: 8.02.2021; Accepted: 9.02.2021; Published: 15.02.2021

\begin{abstract}
The interspecific associations between selected fungal species were calculated based on assumption; the species occurring together in Petri dishes during isolation from litter might be associated as well. Each Petridis was considered as a quadrate for association analysis. The presence and absence of different species in Petri dishes at different sampling dates were recorded as done in grasslands by the quadrate method. In the present study, the interspecific association between 16 fungal species was evaluated, which was isolated during the decomposition of above-ground residues of wheat crop. A sum of 136 combinations was analyzed. The chi-square $\left(\chi^{2}\right)$ values were calculated to assess the significance of association (positive or negative), and the coefficient of association (V) was also enumerated to find out the extent of association between species in nature. Any organism was influenced by abiotic and biotic factors constituting its environment. The fungi are no exception; the colonization of a substrate by a fungus and its survival and multiplication depends upon the environment it gets. Therefore, before using any fungus as a bioinoculant, we must make sure that other microbes, especially the fungi already present on the substrate, do not negatively impact it. An analysis of the association between species colonizing the substrate would help determine the bioinoculant to be used for the degradation of organic waste in the interest of the environment to make it safe for everyone.
\end{abstract}

Keywords: association analysis; chi square $\left(\chi^{2}\right)$; coefficient of association (v); wheat crop; fungal decomposer.

Abbreviations: $\chi 2$-chi-square; V-Coefficient of association; CMC-Carboxymethyl cellulose.

\footnotetext{
(C) 2021 by the authors. This article is an open-access article distributed under the terms and conditions of the Creative Commons Attribution (CC BY) license (https://creativecommons.org/licenses/by/4.0/).
}

\section{Introduction}

The fungi represent a large, diverse group of heterotrophic organisms, the majority of which are originated as saprobes in the soil and on the decomposing organic matter $[1,2]$. These are eukaryotic, having internal membrane systems, membrane-bound organelles, and a well-defined cell wall made of large polysaccharides (glucan, mannan) and chitin [3, 4]. The 
fungi are universal inhabitants of diverse ecosystems sharing morphologically alike characteristics [5-7]. The term 'fungicolous fungi' coined for fungi species that, over and over again, are coupled with other fungi [8,9]. The association between biotic diversity and ecosystem function has received much attention among ecologists [10-13]. The various ecologists discussed earlier whether the positive relationship between diversity and function previously observed in fungi has been due to the importance of species diversity or whether individual species' specific properties are of overriding importance [14-16]. Westerdijk proposed the term association for the specific combinations of microfungi on decaying organic substrates [17]. Among many examples quoted were: (a) the occurrence of Cladosporium herbarum, Alternaria tenuiis and Stemphylium spp. on cereal stubble; (b) the occurrence of $C$. herbarum, A. tenuiis, and Aureobasidium pullulans on weathered cotton [17, 18].

The tribe found that the non-cellulolytic Pythium oligandrum grew on cellulose so long as it was introduced along with cellulolytic Botryotrichum piluliferm [19].Though numerous compounds of highly variable chemical structure enter into the constitution of any litter, a major part of the structural framework is comprised of carbohydrates [20, 21]. Therefore, carbohydrate biochemistry is likely to be the key factor, and any organism is influenced by the abiotic and biotic factors constituting its environment. Therefore, before using any fungus as a bioinoculant, other microbes, especially the fungi already present on the substrate, do not negatively impact it. It can be expected then that the decomposition of a substrate by a fungus or a fungal community depends upon its/their capacity to produce an enzyme(s), which can degrade the substrates' cell wall constituents [22]. Singh et al. had given "good enzymeproducing equipment" as one of the important characteristics contributing towards successful colonization of a dead organic substrate by the fungi because for the invasion of plant tissue by a fungus; the important characteristic is "the rate at which it can penetrate successive cell walls in a cellular tissue [23]. An analysis of the association between the species colonizing the substrate would be helpful in determining the bioinoculant to be used for the degradation of organic waste in the interest of the environment to make it safe for everyone. Moreover, studies reported that Penicillium and Aspergillus species can metabolize complex carbon compounds and the phenolic compounds present in the litter better than other species [24, 25].

Many mycologists have frequently observed fungal succession patterns during litter decomposition. Different fungal taxa dominate different stages of decay in individual ecosystems [26, 27]. However, it is unclear which biological features of fungi give rise to this pattern [28]. Several mycologists tested a longstanding hypothesis that fungal succession depends on species' evolutionary history, such that different fungal phyla prefer different decay stages $[29,30]$. The study was designed to analyze the association between species colonizing the substrate would help determine the bioinoculant to be used for degradation of organic waste in the interest of the environment to make it safe for everyone. This may help select the right inoculants for manipulating the decomposition rate of post-harvested crop residues for sustainable natural resource utilization in eco-friendly agro farming practices. These were positively associated and thought to share common climatic and microhabitat requirements. Some mycoflora preferred the association of certain other fungal species, which played a positive key role in the growth and development of associated mycoflora. A study of the extent and nature of the association between microbes colonizing and decomposing a substrate might help manage crop residues through decomposition. Therefore, the study was taken into consideration. 


\section{Materials and Methods}

The interspecific associations between selected fungal species were calculated based on the assumption that the species occurring together in Petri dishes during isolation from litter might be associated as well. For the purpose of association analysis, each Petri dish was considered as a quadrate. The presence and absence of different Petri dishes species at different sampling dates were recorded as is done in grasslands by the quadrate method [31]. The data for the presence and absence of the species in sampling units were arranged in a tabular form (two into two $(2 \times 2)$ contingency Table 1 ) for all species combinations.

Table 1. The contingency table of species $\mathrm{X}$ and species $\mathrm{Y}$ for all possible combinations.

\begin{tabular}{|c|c|c|}
\hline Species $Y$ & Present & Absent \\
\hline Present & $\mathrm{a}$ & b \\
\hline Absent & c & d \\
\hline
\end{tabular}

Where: $a=$ Number of Petri dishes in which both $X$ and $Y$ were present; $b=$ Number of Petri dishes in which $X$ was absent, but $Y$ was present; $c=$ Number of Petri dishes in which $X$ was present, but $Y$ was absent; $d=$ Number of Petri dishes in which both $\mathrm{X}$ and $\mathrm{Y}$ were absent.

The chi-square $\left(\chi^{2}\right)$ values were calculated using the formula:

$$
\chi^{2}=\frac{n(a d-b c)^{2}}{(a+b)(c+d)(b+d)} \text { where } n=a+b+c+d
$$

If the observed value of $\chi^{2}$ was greater than 3.84 0r 6.64 , the association was considered to be significant or highly significant, respectively. If there was a positive association, most of the quadrates fall in the types ' $a$ ' and ' $d$ '. However, during negative correlation was most of these falls in type ' $b$ ' and ' $c$ '. If the value was less than 3.84 , the association was considered to be insignificant. The strength of association between the two species was further estimated by calculating a coefficient of association, $\mathrm{V}$ [32].

$$
V=\frac{a d-b c}{\sqrt{(a+b)(c+d)(a+c)(b+d)}}
$$

\section{Results and Discussion}

The Chi-square $\left(\chi^{2}\right)$ values were calculated to assess the significance of association (positive or negative), and the coefficient of association (V) was also calculated to find out the extent of association (positive /negative) between the species in nature. In the present study, the interspecific association between 16 fungal species was evaluated; isolated during the decomposition of above-ground residues of wheat crop (Fig. 1; Table 2). About 136 possible combinations were analyzed, out of which 23 combinations were significant (i.e., 15 combinations positively significant, however 8 combinations negatively significant). The coefficient of association between various species combinations was summarized in Table 3 . It showed 18 combinations with significant positive values (Fig. 2). On the contrary, 11 combinations with significant negative associations (Fig. 3). 

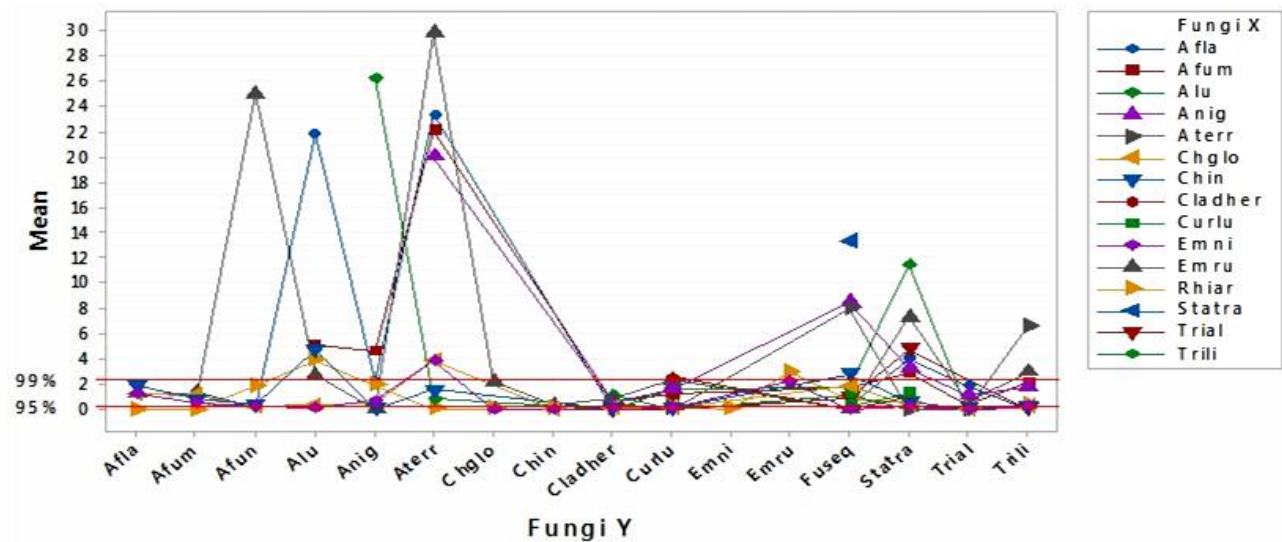

Figure 1. The interaction curve showing chi-square $(\chi 2)$ values for association between various speciescombinations. Where: Rhiar= Rhizopus arrhizus; Emni= Emericella nidulans; Emru= E. rugulosa; Chglo= Chaetomium globosum; Chin=C. indicum; Afla=Aspergillus falvus; Afum=A. fumigatus; Afun= A. funiculosus; $\mathrm{Alu}=$ A. luchuensis; Anig= A. niger $;$ Aterr= A. terreus; Trial= Trichoderma album; Trili= . lignorum; Cladher $=$ Cladosporium herbarum; Curlu=Curvularia lunata; Statra= Stachybotrys atra; Fuseq= Fusarium equiseti.

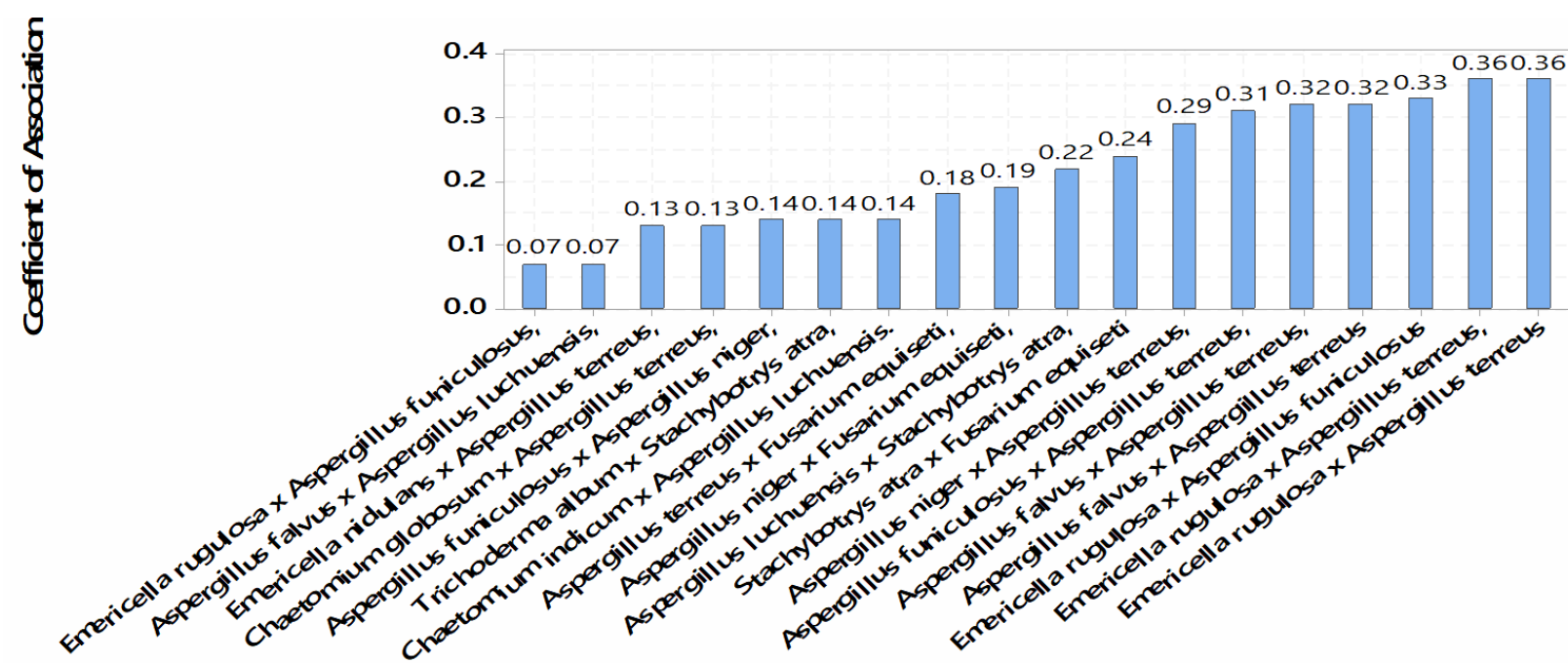

Figure 2. The bar diagram is showing a positive association of fungal species combination based on the value of the coefficient.

The fungal species combinations showed highly positive significant association after advanced numerical tools application based on coefficient values were Emericella rugulosa $\mathrm{x}$ Aspergillus funiculosus, A. falvus x A. luchuensis, E. rugulosa x A. terreus, A. falvus x A. terreus, A. funiculosus x A.s terreus, A. niger x A. terreus, A. luchuensis x Stachybotrys atra, A. niger $\mathrm{x}$ Fusarium equiseti, A. terreus $\mathrm{x} F$. equiseti, S. atra $\mathrm{x} F$. equiseti. However, significant positive associations were recorded against the combinations of A. funiculosus x A. niger, E. nidulans x A. terreus, Chaetomium globosum x A. terreus, Trichoderma album x S. atra, C. indicum $\mathrm{x}$ A. luchuensis. Onthe contrary, some fungal comnations reflected highly significant negative associations based on the values of coefficient such as A. luchuensis x A. niger, E. rugulosa x $S$. atra, A. fumigatus x F. equiseti, A. fumigates $\mathrm{x} S$. atra. While Rhizopus arrhizus x A. luchuensis, A. funiculosus x A. luchuensis, T. lignorum, х A. terreus, A. falvus x S. atra showed the significant values for negative associations. The strongest positive association was recorded between $E$. rugulosa x A. terreus $(\mathrm{V}=+0.36)$ followed by E. rugulosa x A. funiculosus $(\mathrm{V}=+0.33)$ and $A$. falvus x A. terreus $(\mathrm{V}=+0.32)$. On the other hand strongest negative association was noticed between $A$. luchuensis x A. niger $(\mathrm{V}=-0.33)$ followed by A. fumigates $\mathrm{x} F$. equiseti $(\mathrm{V}=-0.28)$ and A. fumigates $\mathrm{x}$ S. atra $(\mathrm{V}=-0.22)$. 


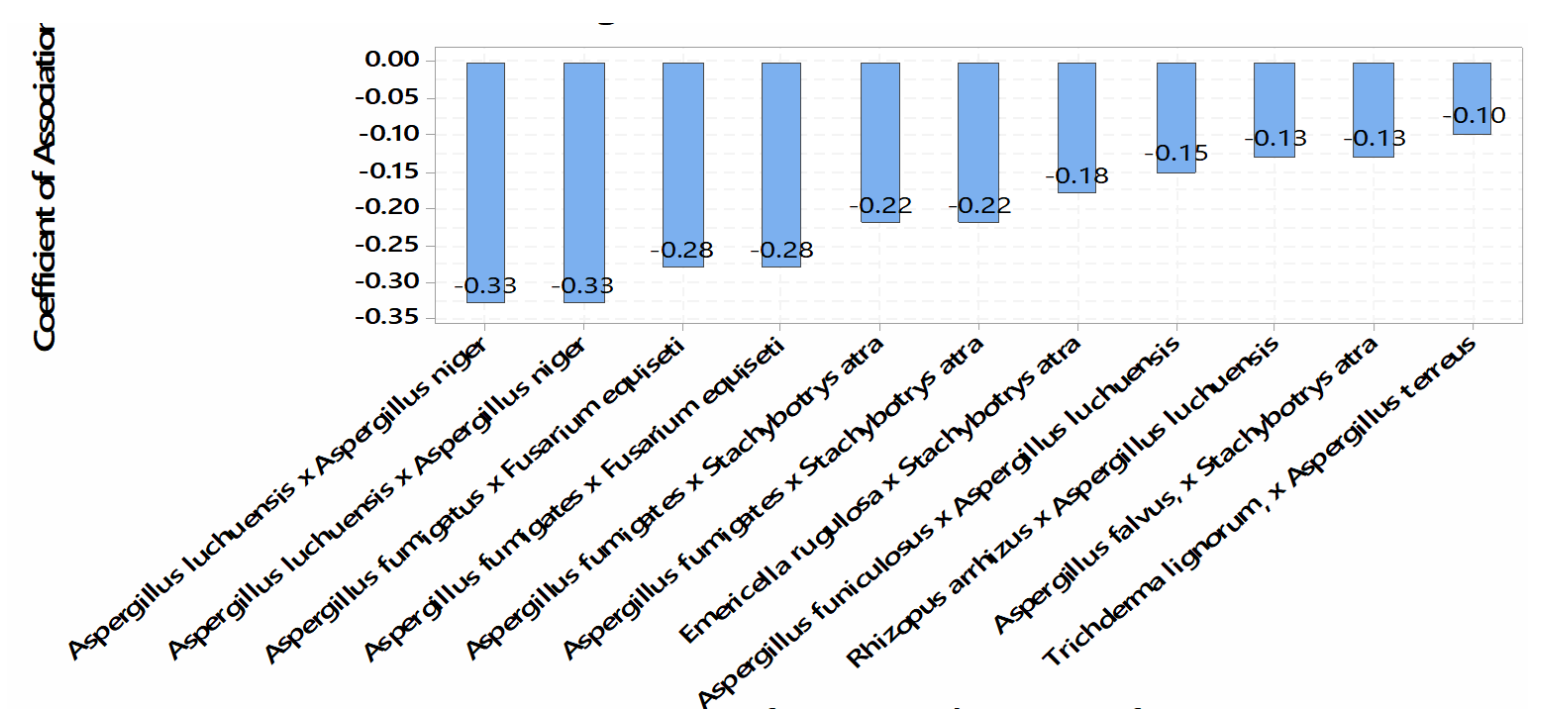

Figure 3. The bar diagram showing a negative association of fungal species combination based on the value of the coefficient.

The Aspergillus niger was found to have a highly significant positive association with A. terreus. The minimum temperature for the mycelial growth of $A$. niger has been found to be $11-13^{\circ} \mathrm{C}$ optimum $17-18^{\circ} \mathrm{C}$ and maximum $47-48^{\circ} \mathrm{C}$ [33-35]. The effect of biotic and abiotic factors on growth and aflatoxin productions have been widely studied using mathematical modeling [36, 37]. For A. terreus, The minimum, optimum and maximum temperature ranges have been determined as $11-13^{\circ} \mathrm{C}, 35-40^{\circ} \mathrm{C}$, and $45-48^{\circ} \mathrm{C}$, respectively $[35,38,39]$. Thus both the species occupy almost similar temperature niches. Both the species can grow at water potential between -210 and -260 bars [40-42]. Both the species tolerate the $\mathrm{pH}$ range $4-8$ very well [43]. While A. terreus possesses $\mathrm{C}_{\mathrm{i}}$ (insoluble cellulose) activity, A. niger does not possess it. On the other hand,A. niger possesses high $\mathrm{C}_{\mathrm{X}}$ (carboxymethylcellulose) activity, A. terreus demonstrates only slight in vitro $\mathrm{C}_{\mathrm{X}}$ activity. On a cellulosic substrate naturally, these two species together can complement each other. The tribe had found that the cellulolytic Pythium oligandrum grew on cellulose as long as it was introduced along with cellulolytic Botryotrichum piluliferum [19].

The $A$. terreus also had a very strong positive association with $A$. flavus. The optimum temperature range for the growth of $A$. terreus, i.e., $35-40^{\circ} \mathrm{C}$ falls well within the optimum temperature range of $A$. flavus, i.e., $25-42^{\circ} \mathrm{C}[35,44]$. The maximum temperature $A$. terreus is $45-48^{\circ} \mathrm{C}$, while for A. flavus it is $47-48^{\circ} \mathrm{C}[39,45-47]$. Both of these show moderate growth from $\mathrm{pH} 4.0-8.0$ [43]. The spores' formation was recorded at $\mathrm{pH} 5$ to 7; however, peak spore formation was observed at a $\mathrm{pH}$ of 5.0. On the contrary lowest sporulation was recorded at $\mathrm{pH}$ 10.0. Thus the trends of spore formation were adversely affected by the $\mathrm{pH}$ of the alkaline range. Likewise, the lowest fresh weight of fungal mycelium was recorded at $\mathrm{pH} 10.0$, which reflected that the higher the $\mathrm{pH}$ towards the alkaline range did not support the growth and development of $A$. parasiticus. Based on the finding, it has been proved that the alkaline medium might be helpful to inhibit the growth of mycelia growth and spore formation in $A$. parasiticus to protect crop damage due to such fungal species [48]. Both of these possess fairly good hemicellulolytic andPectolytic activities and abilities to degrade insoluble cellulose and CMC (carboxymethyl cellulose) in a manner that might complement each other. Thus it is not a surprise that both the above-discussed combinations flourished together on a decomposing substrate. 
In broad-spectrum, the Aspergillus species was notified a comparatively more tolerant myco-flora to $\mathrm{pH}$ towards the alkaline range; on the contrary, the Penicillium species showed its tolerance to a range of acidic $\mathrm{pH}[49,50]$. The findings based on $\mathrm{pH}$ make known to fungi could be able to $\mathrm{pH}$ ranged 3 to 8 . The remarkable augmentation in mycelium's dry weight and trends of sporulation in liquid media were noticed at $\mathrm{pH} 5.5$ and 6.5, respectively [49]. Thus the neutral to a weak acid range of $\mathrm{pH}$ of the medium was appropriate for mycelial growth and conidial production [50]. The optimum temperature for the growth of Stachybotrys atra is $23^{\circ} \mathrm{C}$ with a maximum between $37-40^{\circ} \mathrm{C}$, while for $A$. fumigatus, these are $37-43^{\circ} \mathrm{C}$ and $63^{\circ} \mathrm{C}$, respectively [51]. S. atra is known to produce antifungal metabolites that show antagonistic activities with several fungi. Thus, it is clear that the existence of a positive or negative association between two fungal species may not be purely a matter of chance [52]. A variety of environmental factors like temperature, $\mathrm{pH}$, and physiological capabilities of species and antagonism or synergism between them determine whether any two species would grow together or attempt to exclude/avoid one another [53].

In view of the present study, we should give a second thought before recommending the use of Trichoderma lignorum if the residues are already colonized by sizeable populations of A. terreus; and that of S. atra if the residues are already colonized by Emericella rugulosa, A. fumigatus, or A. flavus [54]. Trichoderma species are one of the most common soil fungi, isolated from various habitats. Many Trichoderma strains are mesophilic and grow well in a wide range of temperatures from $15-35^{\circ} \mathrm{C}$ [55]. The contention draws support from earlier microbiologists' observations who showed that wheat straw failed to respond to microbial inoculation due to the presence of high populations of Clostridium butyricum [56]. On the other hand, co-inoculation of two positively associated species might also prove to be beneficial. Chatterjee and Nandi had noticed that mixtures of microorganisms could degrade lignin and holocellulose of wheat stubbles more efficiently than any individual species, and naturally, combinations of positively associated species might be a better choice in this context as compared to the negatively associated ones [57-62]. There appears to be a dearth of studies on the interactions of straw fungi on natural substrata.

Frankland emphasized comparative studies of fungal combinations to understand the successions of saprotrophic fungi [63]. These studies may have practical implications also. For example, Kanotra and Mathur could achieve improved enzyme titers by co-culturing a mutant strain of T. reesei with a strain of Pleurotus sajor caju with wheat straw as the substrate [60]. Gupte and Madamwar obtained improved hydrolytic and $\beta$ - glucosidase activities by coculturing two strains of A. ellipticus and A. fumigates [61].The association analyses by contingency tables and generalized linear modeling, chi-square values, and coefficient of associations were compared to infer relationships among combinations of fungal species. Both types of statistical approaches were highly congruent with the earlier report. They suggested fungal host preference or shared habitat preferences [64]. The fungi increased significantly in the presence of particular combinations among species, while most associations among fungal species were non-significant. On the contrary, other fungal species were negatively coupled with one and another, conceivably demonstrating diverse habitat preferences. 
Table 2. The Chi-Square $(\chi 2)$ values for an association between various species combinations.

\begin{tabular}{|c|c|c|c|c|c|c|c|c|c|c|c|c|c|c|c|c|}
\hline & & & & & & & 9101 ant & Hatoin & veen vario & pecies col & IIt & & & & & \\
\hline Fungal sp. & Emni & Emru & Chglo & Chin & Afla & Afum & Afun & Alu & Anig & Aterr & Trial & Trili & Cladher & Curlu & Statra & Fuseq \\
\hline Rhiar & 0.04 & 2.95 & 0.04 & 0.06 & 0.03 & 0.0006 & 1.90 & $3.91 *$ & 1.94 & 0.07 & 0.06 & 0.41 & 0.11 & 0.23 & 0.58 & 0.74 \\
\hline Emni & & 2.22 & 0.01 & 0.02 & 1.24 & 0.51 & 0.22 & 0.11 & 0.64 & $3.87 *$ & 0.02 & 0.15 & 0.04 & 0.09 & 0.23 & 0.003 \\
\hline Emru & & & 2.22 & 0.322 & 1.28 & 1.25 & $25.0^{* * *}$ & 2.67 & 0.03 & $29.80 * *$ & 0.53 & 2.93 & 0.81 & 2.31 & $7.30 * *$ & 0.002 \\
\hline Chglo & & & & 0.02 & 1.24 & 1.08 & 0.22 & 0.33 & 0.50 & $3.87 *$ & 0.02 & 0.16 & 0.04 & 0.09 & 0.41 & 1.86 \\
\hline Chin & & & & & 1.88 & 0.78 & 0.34 & $4.73^{*}$ & 0.05 & 1.53 & 0.04 & 0.24 & 0.06 & 0.14 & 0.61 & 2.80 \\
\hline Afla & & & & & & 1.35 & 0.09 & $21.87 * *$ & 2.22 & $23.33 * *$ & 1.88 & 0.06 & 0.07 & 0.29 & $4.02 *$ & 0.22 \\
\hline Afum & & & & & & & 0.14 & 0.35 & 0.02 & 0.06 & 0.87 & 0.37 & 1.20 & 2.68 & $11.74 * *$ & 18.73 ** \\
\hline Afun & & & & & & & & $5.07 *$ & $4.56^{*}$ & $22.07 * *$ & 0.34 & 2.09 & 0.58 & 1.19 & 2.87 & 1.69 \\
\hline Alu & & & & & & & & & $26.23 * *$ & 0.80 & 0.04 & 0.11 & 0.001 & 1.60 & $11.46^{* * *}$ & 1.69 \\
\hline Anig & & & & & & & & & & $19.99 * *$ & 1.15 & 1.70 & 0.48 & 1.61 & $3.25^{*}$ & $8.49 * *$ \\
\hline Aterr & & & & & & & & & & & 0.001 & $6.56^{*}$ & 0.45 & 0.08 & 0.02 & 7.97 ** \\
\hline Trial & & & & & & & & & & & & 0.08 & 0.02 & 0.04 & $4.79 *$ & 0.92 \\
\hline Trili & & & & & & & & & & & & & 1.13 & 0.08 & 0.007 & 1.18 \\
\hline Cladher & & & & & & & & & & & & & & 2.51 & 1.03 & 0.005 \\
\hline Curlu & & & & & & & & & & & & & & & 1.28 & 0.26 \\
\hline Statra & & & & & & & & & & & & & & & & $13.30^{* * *}$ \\
\hline
\end{tabular}

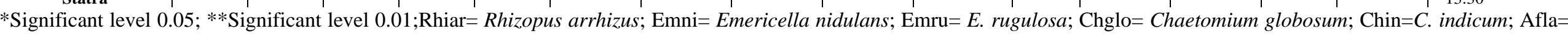

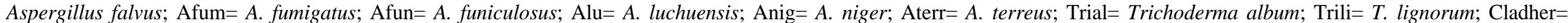
Cladosporium herbarum; Curlu=Curvularia lunata; Statra= Stachybotrys atra; Fuseq= Fusarium equiseti.

Table 3. The coefficient values of association between various fungal species combinations.

\begin{tabular}{|c|c|c|c|c|c|c|c|c|c|c|c|c|c|c|c|c|}
\hline \multicolumn{17}{|c|}{ Coefficient of association between various species combinations } \\
\hline Fungal sp. & Emni & Emru & $\begin{array}{l}\text { Chglo } \\
\end{array}$ & Chin & Afla & Afum & Afun & Alu & Anig & Aterr & Trial & Trili & $\begin{array}{l}\text { Cladher } \\
\end{array}$ & Curlu & Statra & Fuseq \\
\hline Rhiar & -0.04 & +0.11 & -0.01 & -0.01 & +0.01 & -0.001 & +0.09 & -0.13 & +0.09 & +0.01 & -0.01 & -0.04 & -0.11 & -0.03 & -0.05 & -0.05 \\
\hline Emni & & +0.09 & -0.008 & -0.01 & +0.07 & -0.04 & -0.03 & +0.02 & -0.05 & +0.13 & -0.01 & -0.02 & -0.01 & -0.02 & -0.03 & +0.04 \\
\hline Emru & & & +0.09 & $\begin{array}{l}-0.03 \\
\end{array}$ & +0.07 & -0.07 & +0.33 & -0.10 & $\begin{array}{l}-0.01 \\
\end{array}$ & +0.36 & -0.04 & -0.11 & -0.06 & +0.10 & $\begin{array}{l}-0.18 \\
\end{array}$ & +0.003 \\
\hline Chglo & & & & -0.01 & +0.07 & +0.06 & -0.03 & +0.03 & -0.04 & +0.13 & -0.01 & -0.02 & -0.01 & -0.02 & -0.04 & -0.09 \\
\hline Chin & & & & & +0.09 & -0.05 & -0.03 & +0.14 & -0.01 & +0.08 & -0.01 & -0.03 & -0.01 & -0.02 & -0.05 & -0.11 \\
\hline Afla & & & & & & -0.07 & -0.006 & +0.31 & +0.09 & +0.32 & +0.09 & -0.01 & -0.005 & +0.03 & -0.13 & -0.03 \\
\hline Afum & & & & & & & -0.02 & +0.0002 & +0.01 & $\begin{array}{l}-0.01 \\
-0.0\end{array}$ & -0.05 & +0.04 & +0.07 & -0.10 & -0.22 & -0.28 \\
\hline Afun & & & & & & & & -0.15 & +0.14 & +0.31 & -0.03 & -0.09 & -0.05 & -0.07 & -0.11 & +0.06 \\
\hline Alu & & & & & & & & & $\begin{array}{l}-0.33 \\
\end{array}$ & -0.05 & -0.01 & -0.02 & +0.002 & -0.08 & +0.22 & +0.08 \\
\hline Anig & & & & & & & & & & +0.29 & +0.07 & -0.08 & $\begin{array}{l}-0.04 \\
\end{array}$ & +0.08 & -0.12 & +0.19 \\
\hline Aterr & & & & & & & & & & & +0.002 & -0.01 & -0.04 & -0.01 & -0.05 & +0.18 \\
\hline Trial & & & & & & & & & & & & -0.01 & -0.01 & -0.01 & +0.14 & -0.06 \\
\hline Trili & & & & & & & & & & & & & +0.07 & +0.01 & +0.005 & -0.07 \\
\hline Cladher & & & & & & & & & & & & & & +0.10 & -0.06 & $\begin{array}{l}-0.11 \\
\end{array}$ \\
\hline Curlu & & & & & & & & & & & & & & & +0.04 & -0.03 \\
\hline Statra & & & & & & & & & & & & & & & & +0.24 \\
\hline
\end{tabular}

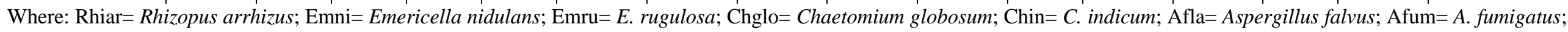

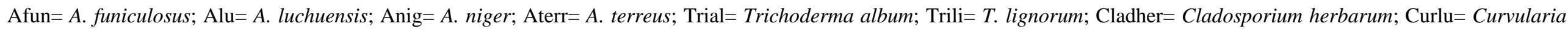
lunata $;$ Statra= Stachybotrys atra $;$ Fuseq= Fusarium equiseti . 


\section{Conclusions}

Understanding the type of association between fungal species, especially the decomposer, may help determine the inoculant species in relation to the dominant mycobiota already existing on the resources. This may help in the selection of the right inoculant for manipulating the rate of decomposition. These combinations were thought to be positively associated and shared widespread climatic and niche necessities. The investigation revealed that some fungal species were expected to associate with certain other species for their suitable growth and development. A study of the extent and nature of the association between microbes colonizing and decomposing a substrate might help manage crop residues through decomposition. It would be better to use those efficient fungal species as Inoculants to withstand the antagonism and competition from the fungal species existing on the residues. An analysis of the association between the species colonizing the substrate would help determine the bioinoculant to be used for the degradation of organic waste in the interest of the environment to make it safe for everyone.

\section{Funding}

This research received no external funding.

\section{Acknowledgments}

Authors are grateful to Hon'ble Vice-Chancellor M.M. Deemed to be University, MullanaAmbala (Haryana), India, for permission to perform collaborative research. The RS and SKU are thankful to Prof. \& Head Department of Biotechnology, MMEC, Mullana-Ambala (HR), India, for continuous encouragement during the investigation.

\section{Conflicts of Interest}

The authors declare no conflict of interest.

\section{References}

1. Naranjo-Ortiz, M.A.; Gabaldon T. Fungal evolution: Major ecological adaptations and evolutionary transitions. Biol. Rev. 2019, https://doi.org/10.1111/brv.12510.

2. Singh, R.; Upadhyay, S.K.; Sharma, I.; Kamboj, P.; Rani, A.; Kumar, P. 2020. Assessment of enzymatic potential of soil fungi to improve soil quality and fertility. Asian J. Biol. Life Sci. 2020, 9(2), 163-8, https://doi.org/10.5530/ajbls.2020.9.25.

3. Greenwood, D.; Slack, R.; Barer, M.; Warnock, D.W. Medical Microbiology $18^{\text {th }}$ edition. Churchill Livingstone. 2012, 794p.

4. Singh, R.; Upadhyay, S.K.; Singh, M.; Sharma, I.; Sharma, P.; Kamboj, P.; Saini, A.; Voraha, R.; Sharma, A.K.; Upadhyay, T.K.; Khan, F. Chitin, chitinases and chitin derivatives in biopharmaceutical, agricultural and environmental perpective. Biointerface Res. Appl. Chem. 2021, 11(3), 9985-10005, https://doi.org/10.33263/BRIAC113.998510005.

5. Gulis, V.; Bärlocher, F. Methods in stream ecology. Vol. I. Ecosystem structure $3^{\text {rd }}$ edition (Hauer FR, Lamber GA). Elsevier Acad Press, 2017, 506p.

6. Frac, M.; Hannula, S.E.; Bełka, M.; Jedryczka, M. Fungal biodiversity and their role in soil health. Front. Microbiol. 2018, 9, 707, https://doi.org/10.3389/fmicb.2018.00707.

7. Schiro, G.; Verch, G.; Grimm, V.; Müller, M.E. Alternaria and Fusarium fungi: Differences in distribution and spore deposition in a topographically heterogeneous wheat field. J. Fungi. 2018, 4(2), 63, https://doi.org/10.3390/jof4020063.

8. Poldmaa, K. Fungicolous fungi. In: Biodiversity of fungi: Inventory and monitoring methods (eds. Mueller GM, Bills GF, Foster MS). Elsevier Acad Press, 2004, 777p.

9. Peralta, R.M.; Silva, B.P.; Gomes, R.C.; Camila, C.; Flavio, G.K.; Vicente, A.; Bracht, S.A. Enzymes from basidiomycetes: Peculiar and efficient tools for biotechnology. In: Biotechnology of microbial enzyme: 
Production, biocatalysis and industrial applications (ed. Brahmachart G). Elsevier Acad Press, 2017, pp11949.

10. Huston, M.A., Aarssen, L.W.; Austin, M.P.; Cade, B.S.; Fridley, J.D.; Garnier, E.; Grime, J.P.; Hodgson, J.; Lauenroth, W.K.; Thompson, K.; Vandermeer, J.H. No consistent effect of plant diversity on productivity. Sci. 2000, 289(5483), 1255, https://doi.org/10.1126/science.289.5483.1255a.

11. Tilman, D.; Kinzig, A.P.; Pacala, S.W. The functional consequences of biodiversity: Empirical progress and theoretical extensions (MPB-33). Princ Univ Press, Princeton USA, 2001, 392p.

12. Polyak, Y.; Bakina, L.; Mayachkina, N.; Polyak, M. The possible role of toxigenic fungi in ecotoxicity of two contrasting oil-contaminated soils-A field study. Ecotoxicol. Environ. Saf. 2020, 202, 110959, https://doi.org/10.1016/j.ecoenv.2020.110959.

13. Mani, A.; Hameed, S.A. Improved bacterial-fungal consortium as an alternative approach for enhanced decolourisation and degradation of Azo dyes: A review. Natl. Environ. Pollut. Technol. 2019, 18(1), 49-64.

14. Wardle, D.A. Communities and ecosystems: Linking the above-ground and belowground components (MPB34). Princ Univ Press, Princeton USA, 2002, 408p.

15. Setälä, H.; McLean, M.A. Decomposition rate of organic substrates in relation to the species diversity of soil saprophytic fungi. Oecology, 2004, 139(1), 98-107, https://doi.org/10.1007/s00442-003-1478.

16. Singh, R.; Upadhyay, S.K.; Komal. Ecofriendly management of paddy crop residues for sustainable environment and development. Biosci. Res. Bull. 2018, 34(2), 59-72, https://doi.org/10.5958/23203161.2018.00009.3.

17. Westerdijk, J. The concept "association" in mycology. Antonie van Leeuwenhoek, 1949, 15(1), 187-9, https://doi.org/10.1007/BF02062645.

18. Singh, R.; Upadhyay, S.K.; Komal. Management of post harvested paddy crop residues by Aspergillus species for sustainable agriculture. Biosci. Res. Bull. 2019, 35(1), 18-25. https://doi.org/10.5958/23203161.2019.00004.X.

19. Tribe, H.T. Interactions of soil fungi on cellulose film. Trans. British Mycol. Soc. 1966, 49(3), $457-66$. https://doi.org/10.1016/S0007-1536(66)80091-8.

20. Singh, R.; Upadhyay, S.K. A Study on the plant litter decomposition using mycoflora for sustainable environment. Plant. Sci. 2019, 2(1), 11-4. https://doi.org/10.32439/ps.v2i1.11-14.

21. Singh, R.; Upadhyay, S.K.; Kumar, A.; Rani, A.; Kumar P. The Succession of mycobiota on the different off ground components of wheat crop residues. Int. J. Pharma. Bio. Sci. 2019, 10(2B), $217-23$. http://dx.doi.org/10.22376/ijpbs.2019.10.2.b217-223.

22. Singh, R.; Upadhyay, S.K.; Rani, A.; Kumar, P.; Kumar, A.; Singh, C. Lignin biodegradation in nature and significance. Veg. 2018, 31(4), 39-44. http://dx.doi.org/10.5958/2229-4473.2018.00091.5.

23. Singh, R.; Upadhyay, S.K.; Rani, A.; Kumar, P.; Singh, M.; Kumar, P.; Kumar, V. A review on enzyme and substrate colonization by microflora. Biosci. Res. Bull. 2018, 34(1), 27-32. http://dx.doi.org/10.5958/23203131.00003.2.

24. Upadhyay, S.K. Allelopathic activities of specific microbial metabolites in the inland prawn fisheries off eastern Uttar Pradesh, India. Int. J. Scient. Res. 2016, 5(2): 415-6. https://doi.org/10.15373/22778179.

25. Fumi, M.D.; Mazzoleni, V.; Novelli, E.; Galli, R.; Busconi, M.; Blaghen, M.; Mclellan, I. Pedologic characteristics and fungi community in unmanaged cork oak forest soil of two Mediterranean regions: Sardinia and Tunisia. IOBC-WPRS Bull. 2014, 101, 31-8.

26. Hattenschwiler, S.; Fromin, N.; Barantal, S. Functional diversity of terrestrial microbial decomposers and their substrates. C. R. Biol. 2011, 334, 393-402. https://doi.org/10.1016/j.crvi.2011.03.001.

27. Kjøller, A.H.; Struwe, S. Fungal communities, succession, enzymes, and decomposition. In: Enzymes in the environment: Activity, ecology and applications (eds. Burns RG, Dick RP). Marcel Dekker NY, 2020, pp 267-84.

28. Gacura, M.D.; Sprockett, D.D.; Heidenreich, B.; Blackwood, C.B. Comparison of pectin-degrading fungal communities in temperate forests using glycosyl hydrolase family 28 pectinase primers targeting Ascomycete fungi. J. Microbiol. Meth. 2016, 123, 108-13. https://doi.org/10.1016/j.mimet.2016.02.013.

29. Bhatnagar, J.M.; Peay, K.G.; Treseder, K.K. Litter chemistry influences decomposition through activity of specific microbial functional guilds. Ecol. Monogr. 2018, 88, 429-44. https://doi.org/10.1002/ecm.1303.

30. Vivelo, S.; Bhatnagar, J.M. An evolutionary signal to fungal succession during plant litter decay. FEMS Microbiol. Ecol. 2019, 95(10), 1-11. https://doi.org/10.1093/femsec/fiz145.

31. Misra, R. Ecology work book. Oxford and IBH Calcutta. 1968, 244p.

32. Krebs, C.J. Ecology: The experimental analysis of distribution and abundance $6^{\text {th }}$ edition. Univ British Columbia, Vancouver. 2009, 744p.

33. Gibson, I.A.S. Crown rot, a seedling disease of groundnuts caused by Aspergillus niger. Trans. Br. Mycol. Soc. 1953, 36, 198-209. https://doi.org/10.1016/S0007-1536(53)80004-5.

34. Ayerst, G. The effect of moisture and temperature on growth and spore germination in some fungi. J. Stored Prod. Res. 1969, 5, 127-41. https://doi.org/10.1016/0022-474X(69)90055-1.

35. Bilai, V.A.; Zakharchenko, V.A. Range of soil micromycete growth temperature. Mycrobiol. Zh. 1971, 33(1), 30-34. 
36. Asurmendi, P.; Barberis, C.; Pacual, L.; Dalcero, A.; Barberis, L. Influence of Listeria monocytogenes and environmental abiotic factors on growth parameters and aflatoxin B1 production by Aspergillus flavus. J. Stored Prod. Res. 2015, 60, 60-6. https://doi.org/10.1016/j.jspr.2014.09.008.

37. Lahouar, A.; Ana, S.M.; Crespo-Sempere, S.; Sanchi, S.V. Effects of temperature, water activity and incubation time on fungal growth and aflatoxin B1 production bytoxinogenic Aspergillus flavus isolates on sorghum seeds. Rev. Argent. Microbiol. 2016, 48(1), 78-85. https://doi.org/10.1016/j.ram.2015.10.001.

38. Pore, R.S.; Larsh, H.W. Aleuri spore formation in four related Aspergillus sp. Mycol. 1967, 59, 318-25. https://doi.org/10.1080/00275514.1967.12018422.

39. Franze, G. Temperatur an sprueche mikroskopis cher booden pilzeauskli matisch und geographis chver schieden enstanderten. Z. Pelernaehr. Bodenk. 1975, 1, 73-87. https://doi.org/10.1002/jpln.19751380110.

40. Chen, A.W.; Soil fungi with high salt tolerance. Trans. Kans. Acad. Sci. 1964, 67, $36-40$. https://doi.org/10.2307/3626677.

41. Pugh, G.J.F.; Dickinson, C.H. Studies in fungi in coastal soils: Gliocladium roseum. Trans. Br. Mycol. Soc. 1965, 48, 279-86. https://doi.org/10.1016/S0007-1536(65)80095-X.

42. Corry, J.E.L. The water relations and heat resistance of microorganisms. Prog. Indust. Microbiol. 1973, 12, 73-108. http://pascalfrancis.inist.fr/vibad/index.php?action=getRecordDetail\&idt=PASCAL7650064352.

43. Charaya, M.U. Taxonomical, ecological and physiological studies on the mycoflora decomposing wheat and paddy crop residues. PhD Thesis CCS Univ. Meerut, India. 1985, 205p.

44. Carlos, A.; Josep, A. Effects of Temperature, $\mathrm{pH}$ and water potential on mycelial growth, sporulation and chlamydospore production in culture of Cylindrocarpon species associated with black foot of grape vines. Phytopathol. Medit. 2012, 51(1), 37-50. https://doi.org/10.14601/Phytopathol_Mediterr-9499.

45. Pidoplichko, N.M. Gribnaya Flora Grubykhkormov. Izvo Akad Nauk Ukr Ssr Kien. 1953.

46. Jackson, C.R. Peanut kernel infection and growth in vitro by four fungi at various temperatures. Phytopathol. 1965, 55, 46-8.

47. Giorni, P.; Magan, N.; Pietri, A.; Battilani, P. Growth and aflatoxin production of an Italian strain of Aspergillus flavus: Influence of ecological factors and nutritional substrates. World Mycot. J. 2011, 4(4), 425-32. https://doi.org/10.3920/WMJ2011.1300.

48. Abubakar, A.; Suberu, H.A.; Bello, I.M.; Abdulkadir, R.; Daudu, O.A.; Lateef, A.A. Effect of pH on mycelial growth and sporulation of Aspergillus parasiticus. J. Plant Sci. 2013, 1(4), 64-7. https://doi.org/10.11648/j.jps.20130104.13.

49. Zhao, H.; Huang, L.; Xiao, CL.; Liu, J.; Wei, J.; Gao, X. Influence of culture media and environmental factors on mycelial growth and conidial production of Diplocarpon mali. Lett. Appl. Microbiol. 2010, 50, 639-44. https://doi.org/10.1111/j.1472-765X.2010.02847.x.

50. Deshmukh, A.J.; Mehta, B.P.; Sabalpara, A.N.; Patil, V.A. In vitro effect of various nitrogen, carbon sources and $\mathrm{pH}$ regimes on the growth and sporulation of Colletotrichum gloeosporioides Penz. and Sacc causing anthracnose of Indian bean. J. Biopest. 2012, 5, 46-9.

51. Bollen, G.J. The selective effect of heat treatment on the microflora of a greenhouse soil. Neth. J. Plant Pathol. 1969, 75, 157-63. https://doi.org/10.1007/BF02137211.

52. Crisan, E.V. Current concepts of thermophilism and the thermophilic fungi. Mycol. 1973, 65, 1171-89. https://doi.org/10.1080/00275514.1973.12019535.

53. Jong, S.C.; Davis, E.E. Contributions to the knowledge of Stachybotrys and Memnoniella in culture. Mycotaxon. 1976, 3, 409-85.

54. Kumar, A.; Azad, C.S.; Kumar, R.; Imran, M. Trichoderma: A potential biocontrol agent for plant disease management. J. Pharma. Phytochem. 2017, 1, 511-2.

55. Mukherjee, P.K.; Latha, J.; Hadar, R.; Horwitz, B.A.; Tmk. A. A MAP kinase of Trichoderma virens, is involved in biocontrol properties and repression of conidiation in the dark. Eukaryot Cell. 2003, 2, 446-55. https://doi.org/10.1128/EC.2.3.446-455.2003.

56. Magan, N.; Hand, P.; Kirwood, I.A.; Lynch, J.M. Establishment of microbial inocula on decomposing wheat straw in soil of different water contents. Soil Biol. Biochem. 1989, 21(1), 15-22. https://doi.org/10.1016/00380717(89)90004-7.

57. Chatterjee, S.K.; Nandi, B. Biodegradation of wheat stubbles by some soil microorganisms. Proc. RRAI. Symp. PAU, Ludhiana, 1980, 275-80.

58. Bowen, R.M. Decomposition of wheat straw by mixed cultures of fungi isolated from arable soils. Soil Biol. Biochem. 1990, 22, 401-6. https://doi.org/10.1016/0038-0717(90)90119-K.

59. Robinson, C.H.; Dighton, J. Frankland, J.C. Resource capture by interacting fungal colonizers of straw. Mycol. Res. 1993, 97(5), 447-58. https://doi.org/10.1016/S0953-7562(09)81178-7.

60. Kanotra, S.; Mathur, M.S. Isolation and Partial characterization of mutants of Trichoderma reesei and its application in solid state fermentation for paddy straw alone or in combination with P. sajor-caju. J. Environ. Sci. Hlth. 1995, 30A(6), 1339-60.

61. Gupte, A.; Madamwar, D. Production of cellulolytic enzymes by co-culturing of Aspergillus ellipticus and Aspergillus fumigatus grown on bagasse under solid state fermentation. Appl. Biochem. Biotech. 1997, 62, 267-74. 
62. Islam, N.F.; Borthakur, S.K. Study of fungi associated with decomposition of rice stubble and their role in degradation of lignin and holocellulose. Mycosphere. 2011, 2(6), 627-35. https://doi.org/10.5943/mycosphere/2/6/3.

63. Frankland, J.C. Mechanisms in Fungal succession. In: Fungal Community $2^{\text {nd }}$ edition. (eds. Carroll GC, Wicklow DT). Marcel Dekker, NY, 1992, 383-401.

64. Jumpponen, A.; Claridge, A.W.; Trappe, J.M.; Lebel, T.; Claridge, D.L. Ecological relationships among hypogeous fungi and trees: Inferences from association analysis integrated with habitat modeling. Mycol. 2004, 96(3), 510-25. 